\title{
EXPLORING THE DYNAMICS OF IDENTITY BASED CONFLICT AND THE POSSIBILITY FOR ITS SUSTAINABLE MANAGEMENT: A STUDY OF THE PERSISTENT ETHNO-RELIGIOUS CONFLICT IN WUKARI AREA OF TARABA STATE, NIGERIA
}

\author{
Jude A. Momodu, G.I. Matudi, and Abiodun L. Momodu \\ Federal University of Technology \\ (now Modibbo Adama University of Technology) \\ Yola- Adamawa State, Nigeria
}

\section{INTRODUCTION}

Nigeria is a multi-cultural society with over 250 ethnic groups as well as three major religious groups namely Christianity, Islam and African Traditional Religion (ATR). With an estimated population of about 200 million people, "the Hausa-Fulani, the Yoruba and the Igbo account for almost half of Nigeria's population, and many smaller groups tend to cluster around these three, creating a tri-polar ethnic structure around which competition strategies intensify" (CRISE Working Paper 44, March 2007). The Human Rights Watch report also observes that, "the country is divided along religious lines, with the boundaries between Muslim and Christian often overlapping with some of the most important ethnic and cultural divides" (Human Rights Watch, 2006).

The cultural diversity of the Nigerian state naturally creates a platform for competitive struggles between and among the existing interest groups. For instance, since the return to democratic governance on May 29,1999 , the country has witnessed very violent and turbulent ethnic and religiously induced conflicts, some of which have seriously shaken its political, economic and social foundations to the extent that the country's 'hard earned' Fourth Republic has been on the brink of collapse. This ominous trajectory currently facing the Nigerian state has made Professor Isaac Olawale Albert argue that:

Since Nigeria transited from military dictatorship to multi-party democracy on 29 May, 1999. The country has been bedeviled by various forms of violent social conflicts. Thousands of people lost their lives, were maimed or displaced from their communities as a result of these problems. While some of the conflicts had their 
roots in the past historical circumstances of the concerned communities, some others were "manufactured" by the elites, seeking to stretch the liberty inherent in the new democratic process in Nigeria to a breaking, if not absurd point (Albert, 2001).

The reality of this situation is that the Nigerian elites often find it very convenient to employ ethnicity and religion as tools in order to manipulate Nigerians in their power play game, owing to the hypnotic and manipulative power of ethnicity and religion on Nigerians. As Momodu rightly observes:

Religious and ethnic manipulations hold sway between and among ethnic groups with large number of illiterate populations and high incidence of poverty. This situation makes it possible for ethnic or religious entrepreneurs to assume the role of 'messiahs' or 'freedom fighters' for their ethnic or religious groups. In actual fact, the goals and interests that they seek to achieve are disguised as those of their ethnic or religious groups, which they claim to represent. Whenever these goals and interests appear to be threatened, they fan the embers of ethnic or religious hatred and conflict between their own ethnic or religious groups against the ethnic or religious group they perceive to be threatening their goals, using them as 'ethnic or religious sacrificial lambs' for the sole purpose of achieving their own selfish ends (Momodu, 2014-emphasis added).

Ethnicity and religion play a very important role both in the private and public lives of Nigerians and this is affirmed by an authoritative survey carried out in 2000 on Attitudes to Democracy and Markets in Nigeria, which notes that ethnicity "is demonstrably the most conspicuous group identity in Nigeria" (Lewis and Bratton 2000). Thus, the survey found out that almost one-half (48.2\%) of Nigerians chose to label themselves with an ethnic (including linguistic and local-regional) identity, compared to almost one-third (28.4\%) who opted for class identities, and 21.0 percent who chose a religious identity (Lewis and Bratton 2000). The study specifically indicated that "Nigerians tend to cluster more readily around the cultural solidarities of kin than the class solidarities of the workplace" (Lewis and Bratton 2000).

The findings of the above scholars point to the fact that most Nigerians, about two-thirds of the country's population, show more loyalty to their ethnic and religious constituencies. This places both ethnicity and religion in a serious competition for the soul of the Nigerian state, just as 
God and the devil are competing for the soul of humanity. This dangerous competition has often bred violent ethno-religious conflicts in the country. Salawu (2010) observed that "about $40 \%$ of ethno- religious conflicts are credited to the fourth Republic of Nigeria, while observers have equally described the situation as a permanent feature of the Nigeria state," ethno-religious conflicts tend to always stretch the bounds of unity to a potential snapping point (Jega, 2002).

Inter-group relations in Nigeria are largely determined by ethnic, religious, economic and cultural factors thus creating fault-lines in most Nigerian communities. In particular, inter-group relations between and among ethnic and religious groups in Nigeria are characterized frequently by mutual suspicion and hatred to the extent that at the slightest provocation conflict is inevitable between communities; in most cases assuming very violent dimensions. This is the reason for instance why Okwueze (1995) rightly observed that, "Nigeria is one of the countries where religion and ethnic conflicts have wrecked much havoc on the advancement, unity and prosperity of her citizens and the development of the nation as a whole."

Nigeria is also one of the African countries most severely affected by violence. It is ranked 148 out of 162 countries worldwide in the Global Peace Index (Vision for Humanity, Global Peace Index, 2013). It has the third largest number of political violence events in Armed Conflict Location \& Event Dataset (ACLED), and it is ranked 16th in the Fund for Peace Failed States Index 2013 (Fund for Peace, 2013). A 2012 survey of Nigerians on crime and victimization by the CLEEN Foundation found that, on average, $5 \%$ of respondents had personally been victims of armed violence (CLEEN Foundation, 2012).

There are many ethno-religious conflicts that have occurred in $\mathrm{Ni}$ geria. For instance, Mohammed (2005) contends that before the present democratic dispensation in Nigeria, there were ethno-religious conflicts that claimed so many lives and property. Some examples of such crises include: the Maitatsine religious disturbances that ravaged parts of Kano, Bauchi, and Maiduguri in the early 1980s, which also spilled over to Jimeta-Yola 1984; the Zango Kataf crises in Kaduna State 1992; and the Kafanchan College of Education Muslim-Christian riots and Kaduna Polytechnic Muslim-Christian skirmishes 1981 and 1982. There are also other incidents of ethno-religious conflicts including: the Bulum kutu Christian-Muslim riots 1982; Usman Danfodio University Sokoto 1982; and the Muslim-Christian clash during a Christian procession at Easter in Ilorin, Kwara State 1986. Other examples are the ethno -religious conflict of July 18, 1999 between the Oodua people congress and Hausa traders at Shagamu in Ogun State; the February ethno-religious crisis between Zagon and Kataf communities in Kaduna State between 1999- 
2001; and the protracted ethno- religious conflict in Jos, plateau State in 2001, 2002, 2008, 2010 and 2011. And of course, the protracted ethnoreligious conflicts in Wukari Local Government Area of Taraba State which started from 2000 to date, which is the central focus of this paper. The following thematic areas form the basis for discussion in this paper:

- Literature review, conceptual clarifications and theoretical framework,

- Origin and causes of ethno-religious conflicts in Wukari Local Government Area of Taraba State,

- Costs of ethno-religious conflicts on inter-group relations in Wukari Local Government Area of Taraba State,

- Suggested solutions to the management of ethno-religious conflicts on inter-group relations in Wukari Local Government Area of Taraba State, and

- Conclusion.

Literature Review, Conceptual Clarifications and Theoretical FRAMEWORK

\section{CONCEPTUAL CLARIFICATIONS}

\section{RELIGION}

Religion, according to Adeniyi (1993), refers to a body of truths, laws and rites by which man is subordinated to the transcendent being. This implies that religion deals with norms and rules that emanated from God and which must be followed by the believers. Ejizu (1993) provides another definition of religion. According to him, religion is man's intuition of the sacred and ultimate reality and his expression of that awareness in concrete life. In essence, religion can be defined as the belief system held by a group of people towards a supreme being which they revere and believe can guarantee their security and welfare and their existence here on earth and in the hereafter.

\section{ETHNIC GROUP}

The term "ethnic" is derived from a Greek adjective ethnikos, meaning "national, foreign, gentile." The adjective is derived from the noun ethnos, "people, nation, foreign people," that in the plural phrase ta ethn meaning "foreign nations" (The American Heritage Dictionary of the English Language, Fourth Edition, 2000). However, the task of defining ethnic group is somewhat difficult. Hence, many scholars believe that definitions of what constitutes an ethnic group or an ethnic minority are subject to much discussion (see Coleman and Salt, 1996; Bulmer, 1996; Ballard, 1996; Solomos and Black, 1996). 
The variations in the definitions of ethnic group and the lack of agreement among scholars on what should constitute the meaning of an ethnic group is responsible for the multiplicity of definitions on the concept by various scholars in ethnic studies, ethnic conflict, sociology, political science and related disciplines. However, the common denominators in the many descriptions that have been given to ethnic group are: people residing within the same geographical territory, people who share the same historical memories, common origins, common identity, language, culture, and aspirations. What really is an ethnic group? Modood; Berthoud; Lakey; Nazroo; Smith; Virdee and Beishon (1997) define an ethnic group as a community whose heritage offers important characteristics in common between its members and which makes them distinct from other communities. There is a boundary, which separates 'us' from 'them', and the distinction would probably be recognized on both sides of that boundary. Quaker-Dokubo (2001) also perceives ethnic group as pertaining to organized activities by persons linked by a consciousness of a special identity, who jointly seek to maximize their corporate political, economic and social interest. Willigenburg (1995) refers to ethnic group as "cultural nations which are bound together in the first place by a common culture and which lack the internationally recognised organization of a sovereign state".

\section{Ethno-Religious Conflict}

Ethno-religious conflict refers to a situation in which members of an ethnic group practicing the same religion engage in mutually opposing coercive interactions with members of another ethnic group practicing the same but different religion from the former group. Ethno-religious conflict is often characterised by a mixture of both ethnic and religious agitations. It is also a situation in which at least the interests or goals of members of an ethnic group who belong to the same religious group are in opposition to the interests or goals of another ethnic group practicing the same religion but different from the former group is exclusively defined in ethnic and religious terms. Ethnicity and religion are tools for identity construction by the elites who draw on the mesmerizing and manipulative tendencies of both ethnicity and religion in competitive situations. The combination of ethnicity and religion for identity construction produces a strong platform for identity mobilization.

\section{THEORETICAL FRAMEWORK}

\section{TERRITORIAL IMPERATIVE THEORY}

The study also adopted the theory of Territorial Imperative developed by Robert Ardrey in 1967, in which he traced the animal origin of 
property, nations and territoriality. A territory is defined as an area of space which an animal or group of animals defend as an exclusive preserve. It is within such territory that the basic needs and interests of such animals are gratified. These needs include: security of space and food, identity, prestige, etc. They therefore defend such an area at all costs and strive to keep it out those who undermine their interests and needs. Following the above postulation, all animals, including man, have the natural tendency or instinct to be territorial and possessive, especially when their territories and possessions are threatened. In order to ward-off this threat, they will employ any means available to them to defend their territories and possessions. This is the reason why Ardrey (1967) opined that "if we defend the title to our land or the sovereignty of our country, we do it for reasons no different, no less innate, no less ineradicable, than do lower animals."

In the same manner, Sherif and Sherif (1969) support this view by arguing that territorial aggression in animals is based on the relatively simple chemical, tactile and visual discriminations involved in detecting unfamiliar 'opponents' while for humans the concept of 'territory' depends on complex cultural symbolizations of property or 'homeland'. People, they pointed out, are quite capable of territorial loyalty without actually living in the territory itself. Therefore, conflict may ensue in an attempt by individuals, groups, or countries to defend their territories, land, traditions, culture, and property they so value. For instance, TorTiv, the paramount ruler of the Tiv people observes that "in many traditions, land matters are closely tied to the custom of the people; hence it could be very volatile" (Torkula, 2002).

This, in part, explains the reasons why ethnic groups fight over land and territory. Indeed, scholars have argued that territorially concentrated groups in divided societies are more likely to demand self-determination (Saideman and Ayres, 2000 and Toft 2003; Toft and Saideman 2010) and to be engaged in violent conflict in its pursuit (Fearon and Laitin 1999; Weidmann, Rod, Cederman 2010). This also explains the situation of the protracted ethno-religious conflicts in Wukari between the Jukun Christians allied with the Jukun traditionalists versus the Jukun Muslims supported by Hausa Muslims. The latter feels threatened by the resolve of the former to chase them out of their ancestral land and also deprive them of participating in both the political affairs of Wukari Local Government and in the Traditional Council of Wukari. As a result, the two groups have been engulfed in a fierce battle for the contest over who owns Wukari land and who is qualified to enjoy the rights and benefits of being indigenes of Wukari Local Government Area of Taraba State. The conflict between the two groups in Wukari, Taraba State is a classic example of a struggle over territory and ethnic dominance. 


\section{Origin and Causes of Violent Ethno-Religious Conflicts in Wukari Local Government ARea of Taraba State, Nigeria}

Inter-group relations among communities in Nigeria is rooted in the colonial history of the Nigerian state. However, inter-group relations in Nigeria predate the pre-colonial era and as a matter of fact, inter-group relations among Nigeria's pre-colonial societies could be said to be both harmonious and conflictive and span diverse areas such as: cultural exchanges, commerce, politics, and social spheres. But one fascinating aspect of inter-group relations in the Nigerian pre-colonial societies was that ethnic migrants were in many places integrated and assimilated into their host communities, even inter-marrying. Buttressing this argument, Olaniyi (2001) cites the case of Yoruba Ayagi quarters in Kano who after a century of settlement had been assimilated into Hausa culture. Usman (1981) describes a similar assimilation process in respect to diverse groups that migrated into Katsina and became "absorbed into the households patronages through marriages and cohabitation."

The colonial political economy further increased the migration of Hausa people into Yoruba land. This was due to the emergence of the colonial capitalist economy which introduced taxes and opened up roads and railways linking all the major cities of Nigeria. Hopkins (1973) believes that such factors encouraged and facilitated the increase in migration of Nigerians generally. Furthermore, Swindell (1984) observes that "as the twentieth century developed, labour migration clearly took on new dimension and, from what can be inferred, there was a rapid increase in the volume of migration to meet new levels of taxation and demands for labour in the towns and commercial crop zones." Consequently, this trend has heightened competition for the available scarce resources between hosts and settlers across major towns in Nigeria until today. This is also the case with Wukari Local Government Area of Taraba State, which is an amalgam of different ethnic and religious populations and has consequently witnessed many violent ethnic and religiously induced conflicts.

Recently, Wukari has been experiencing a protracted ethno-religious conflict and the main cause of the conflict has been the struggle for the control of Wukari land and, by extension, competition for the economic and political resources in the area between the Jukun Christians allied with the Jukun traditionalists and the Jukun Muslims supported by Hausa Muslims in the area. Both parties hold tenaciously to their disparate narratives which they often express. On one hand, the Jukun Christians in alliance with the Jukun traditionalists accuse the Jukun Muslims supported by Hausa Muslims of wanting to deliberately and systematically violate the Jukun traditional culture by planning to politically con- 
trol Wukari. The Jukun Christians, who consider themselves not only the owners of Wukari land but also the custodians of the Jukun traditional culture, are prepared to spill their last blood to defend it from the encroachment of the Muslim Jukun supported by the Hausa Muslim settlers on Wukari land.

On the other hand, the Jukun Muslims supported by Hausa Muslims accuse the Jukun Christians and the Jukun traditionalists of excluding them from the political control of Wukari Local Government Area as well as from the traditional Council. These are the real issues in the conflict and these issues have encouraged the politicization of both ethnic and religious identities in Wukari area. This is so because scholars have argued that ethnic and religious conflicts are rooted in the politicization of ethnic and religious identities and the competition and conflict for political power by the ethnic and religious communities respectively (Anarfi, 2004; Conversi, 1999). More specifically, Takaya (1992:112) identified centrifugal factors that gave rise to the politicization of ethnic and religious identities in Nigeria, which include:

(i) the existence of two or more ethnic and religious groups with numerical strengths that can significantly affect the outcome and direction of a democratic political process;

(ii) the instrumentalization of ethnicity and religion as a legitimizing tool of hegemony in instances when the interests of the political class are under threat;

(iii) when there is an ascendant radical thinking within a politically significant ethnic or religious group capable of upstaging hegemony;

(iv) when the society is characterized by political, social or economic hardships that can cause alliances along ethnic and religious faultlines.

The persistent conflicts between Jukun Christians/Jukun traditionalists versus the Jukun Muslims supported by Hausa Muslims have led to loss of many lives and the destruction of much property and have distorted inter-group relations in the Wukari community. The mixture of ethnicity and religion have taken the situation between the warring groups to unimaginable and deadly heights such that brothers and sisters who have the same ancestral linkage and have co-existed in harmony for centuries have suddenly turned on one another with murderous fervor, a situation re-enforced by bitter and dangerous politics.

The vulnerability of the Wukari community to violent conflicts can be attributed mainly to factors such as: the contest for indigeneship of Wukari LGA; competition for political, social and economic space; the problem of youth unemployment; and arms proliferation in the area. It is in the light of these factors that Mitchell (2000) asserts that conflicts 
involving settlers and natives usually revolve around the question of land, and in most cases around the quest by settlers to dispossess the natives of their land through what he called migratory overcrowding. Mitchell's assertion can be said to be true about the Wukari community which is an area that is agriculturally rich and has often resulted in violent competition for resources between the Jukun, who consider themselves as the natives of Wukari, against the other ethnic groups such as Tiv, Fulanis and Hausa communities in Wukari.

The Jukun Christians/Jukun traditionalists believe that the Hausa/ Fulani settlers are collaborating with the Jukun Muslims and that their hidden agenda is to Islamize and take over Jukun land. This suspicion of the Jukun Christians and Jukun traditionalists is also the same one that is held by most host communities where the Hausa/Fulani groups are settled. This accounts for why the Hausa/Fulani settlers are much resented, which along with their domineering tendencies, makes the host communities discriminate against them. Best (2006) has rightly observed that "the struggle of ethnic minorities, framed by their experience of domination, tends to be targeted primarily against the Hausa/Fulani, and indirectly against the Nigerian State". The mobilization of religious and ethnic sentiments and solidarity towards gaining control over Wukari land has been fueling violent conflicts between the Jukun Christians in alliance with the Jukun traditionalists against the Jukun Muslims also in alliance with the Hausa settlers in Wukari.

Another major cause of the violent ethno-religious conflicts in Wukari is the availability of small and big arms in the area. For instance, Wukari has witnessed so many violent conflicts such as the protracted violent conflicts between the Jukun and Tiv which, according to Momodu (2014), is:

One of the most violent and recurring ethnic conflicts that have occurred in Nigeria and the periodic clashes between the two groups span from the 1860 s to 1899 , 1904, 1950s, 1964, 1976, 1987; and from 1990-1993 and 2001-2002, it climaxed into violent warfare. The human, economic, political, social and psychological costs associated with these perennial conflicts are colossal and some of these costs are still very visible in Wukari (Momodu, 2014).

Wukari has also witnessed pockets of skirmishes between the Tiv and Fulani, Jukun and Fulani as well the current persistent ethno-religious conflicts in the area. These several crises have deeply entrenched the culture of violence in inter-group relations in the area. Momodu (2014) established that, "the free usage of arms especially by the Tiv and Jukun militias to kill and maim indicates the magnitude of proliferation of arms 
in Wukari and its environs and it also suggests the vulnerability of Wukari to violent conflicts." This situation therefore underscores the "privatisation of violence that challenges the monopoly of violence as a defining feature of the state" (Debiel, 2002). The proliferation of arms in Wukari has made the area unstable and unsecured.

Clearly, the Wukari community is Balkanized along ethnic and religious fault lines thus resulting in a situation where the Jukun Christians lack confidence or trust in their fellow Jukun Muslims or Hausa/Fulani settlers in Wukari community. As a result, there currently exists a psychological and physical fault line between the Jukun Christians and Jukun Traditionalists on one hand and on the other hand the Jukun Muslims and Hausa/Fulani. This situation has often given the impetus for violent conflicts. This tendency if not checked will continue to create instability in the area, which is the way in which it is currently playing out.

IMPACT OF ETHNO-RELIGIOUS CONFLICTS ON INTER-GROUP RELATIONS IN Wukari Local Government of Taraba State

The following table is the time line of violent conflicts in Wukari Local Government Area of Taraba State, Nigeria between 2000 up till date.

Time Line of Violent Ethno-Religious Conflicts in Wukari L.G.A. FROM 2000 - 2014

\begin{tabular}{|l|l|l|l|}
\hline S/no: & Triggers & Period & Casualties \\
\hline 1. & $\begin{array}{l}\text { The destruction of a mosque under } \\
\text { construction at the premises of FRSC } \\
\text { Office Wukari by Jukun youths led to } \\
\text { a violent conflict between the } \\
\text { Christians and Muslims }\end{array}$ & Early 2000 & $\begin{array}{l}18 \text { people were } \\
\text { killed while } \\
\text { several properties } \\
\text { were destroyed }\end{array}$ \\
\hline 2. & $\begin{array}{l}\text { An argument between a royal prince } \\
\text { and some Muslim youths over right } \\
\text { of way led to a violent conflict } \\
\text { between Jukun Christians and Hausa/ } \\
\text { Jukun Muslims }\end{array}$ & $\begin{array}{l}\text { October 17, } \\
\text { 2005 }\end{array}$ & $\begin{array}{l}7 \text { people were } \\
\text { killed while } \\
\text { several properties } \\
\text { were destroyed }\end{array}$ \\
\hline 3. & $\begin{array}{l}\text { The demolition of a mosque built at } \\
\text { the Area Command Headquarters of } \\
\text { the Nigeria Police by Jukun Christian } \\
\text { Youths led to violent conflict between } \\
\text { Christian Jukun and Hausa / Jukun } \\
\text { Muslims }\end{array}$ & $\begin{array}{l}\text { July 13, 2010 } \\
\text { 10 people were } \\
\text { killed while } \\
\text { several others } \\
\text { were injured and } \\
\text { several properties } \\
\text { destroyed. Over } \\
\text { 2000 people were } \\
\text { displaced. }\end{array}$ \\
\hline
\end{tabular}




\begin{tabular}{|c|c|c|c|}
\hline 4. & $\begin{array}{l}\text { The accidental shooting of a Jukun } \\
\text { youth during an argument over the } \\
\text { use of a football field by two } \\
\text { opposing teams triggers a violent } \\
\text { ethno-religious conflict }\end{array}$ & $\begin{array}{l}\text { February 23, } \\
2013\end{array}$ & $\begin{array}{l}340 \text { people were } \\
\text { killed, several } \\
\text { properties } \\
\text { destroyed while } \\
\text { several people } \\
\text { were displaced. }\end{array}$ \\
\hline 5. & $\begin{array}{l}\text { A misunderstanding between } \\
\text { Christians and Muslims during the } \\
\text { burial procession of one of the Jukun } \\
\text { Traditional Rulers led to a violent } \\
\text { conflict }\end{array}$ & May 3, 2013 & $\begin{array}{l}\text { Over } 500 \text { people } \\
\text { were killed while } \\
\text { several people } \\
\text { were in jured. More } \\
\text { than } 100 \text { buildings } \\
\text { were destroyed } \\
\text { and over } 3,000 \\
\text { people displaced. }\end{array}$ \\
\hline 6. & $\begin{array}{l}\text { Armed Fulani herdsmen attacked } \\
\text { Ando-Manu village in Wukari LGA }\end{array}$ & April 3, 2014 & $\begin{array}{l}\text { The Village Head } \\
\text { was killed and } \\
\text { several people } \\
\text { were injured, } \\
\text { while several } \\
\text { villagers in the } \\
\text { area were } \\
\text { displaced to } \\
\text { Wukari town. }\end{array}$ \\
\hline 7. & $\begin{array}{l}\text { Armed Jukun Youths attacked Jibu } \\
\text { town for allegedly harboring and } \\
\text { accommodating Fulani herdsmen that } \\
\text { attacked Ando Manu village }\end{array}$ & April 7, 2014 & $\begin{array}{l}73 \text { people were } \\
\text { killed while } \\
\text { several others } \\
\text { were injured }\end{array}$ \\
\hline 8. & $\begin{array}{l}\text { A reprisal attack by Fulani herdsmen } \\
\text { from Jibu town against Jukuns in } \\
\text { Nwokyo village for attacking Fulani } \\
\text { herdsmen in Jibu }\end{array}$ & $\begin{array}{l}\text { April 14, } \\
2014\end{array}$ & $\begin{array}{l}3 \text { people were } \\
\text { killed in Nwokyo } \\
\text { village and more } \\
\text { than } 15 \text { houses } \\
\text { were destroyed } \\
\text { with several } \\
\text { people displaced }\end{array}$ \\
\hline 9. & $\begin{array}{l}\text { The attack on Nwokyo village by } \\
\text { Fulani herdsmen led to a violent } \\
\text { ethno-religious crisis between Jukun } \\
\text { Christians and Hausa/Jukun Muslims }\end{array}$ & $\begin{array}{l}\text { April 15, } \\
2014\end{array}$ & $\begin{array}{l}\text { Over } 273 \text { people } \\
\text { were killed, } 48 \\
\text { houses burnt and } \\
\text { several people } \\
\text { injured. Also, over } \\
5000 \text { people were } \\
\text { displaced }\end{array}$ \\
\hline 10. & $\begin{array}{l}\text { The April 15th crisis in Wukari } \\
\text { spilled over to Gindin-Dorowa town }\end{array}$ & $\begin{array}{l}\text { April 19th, } \\
2014\end{array}$ & $\begin{array}{l}\text { Over } 120 \text { people } \\
\text { were killed with } \\
\text { several properties } \\
\text { destroyed and a lot } \\
\text { of people were } \\
\text { displaced to } \\
\text { Wukari town }\end{array}$ \\
\hline 11. & $\begin{array}{l}\text { Jukun youths attacked Chinkai village } \\
\text { in reprisal attack against Hausa / } \\
\text { Jukun Muslims }\end{array}$ & $\begin{array}{l}\text { May 25th, } \\
2014\end{array}$ & $\begin{array}{l}62 \text { people were } \\
\text { killed while over } \\
40 \text { buildings were } \\
\text { burnt down and } \\
\text { lots of people } \\
\text { were displaced }\end{array}$ \\
\hline
\end{tabular}




\begin{tabular}{|c|c|c|c|}
\hline 12. & $\begin{array}{l}\text { Another violent ethno-religious } \\
\text { conflict erupted between the Jukun } \\
\text { Christians and Jukun/Hausa Muslims } \\
\text { as result of the burning of a phone } \\
\text { booth owned by a Hausa Muslim by } \\
\text { an unknown assailant. }\end{array}$ & $\begin{array}{l}\text { June } 15 \text { th, } \\
2014\end{array}$ & $\begin{array}{l}\text { About } 300 \text { people } \\
\text { were killed, while } \\
\text { over } 200 \text { buildings } \\
\text { were destroyed in } \\
\text { Wukari metropolis. }\end{array}$ \\
\hline 13. & $\begin{array}{l}\text { The violence that erupted on the } 15 \text { th } \\
\text { of June in Wukari spilled over to } \\
\text { Rafin Kada, a neighbouring Jukun } \\
\text { settlement. }\end{array}$ & $\begin{array}{l}\text { June } 15 \text { th } \\
2014\end{array}$ & $\begin{array}{l}\text { About } 30 \text { people } \\
\text { were killed, while } \\
\text { a lot of buildings } \\
\text { were also } \\
\text { destroyed. }\end{array}$ \\
\hline 14. & $\begin{array}{l}\text { Un-known gun men from Ibi and } \\
\text { Bantaji towns, attacked Nwuban, a } \\
\text { Jukun Village, in Wukari Local } \\
\text { Government Area. }\end{array}$ & $\begin{array}{l}\text { August 17th, } \\
2014\end{array}$ & $\begin{array}{l}\text { About } 13 \text { were } \\
\text { reportedly killed } \\
\text { and many } \\
\text { properties worth } \\
\text { thousands of Naira } \\
\text { were destroyed as } \\
\text { well as many } \\
\text { people displaced } \\
\text { from their homes. }\end{array}$ \\
\hline 15. & $\begin{array}{l}\text { Another violent ethno-religious } \\
\text { conflict erupted in Wukari. }\end{array}$ & $\begin{array}{l}\text { September } \\
\text { 2nd, } 2014\end{array}$ & $\begin{array}{l}\text { About people were } \\
\text { reported killed } \\
\text { while several } \\
\text { properties were } \\
\text { destroyed and } \\
\text { many people were } \\
\text { displaced from } \\
\text { Wukari town. }\end{array}$ \\
\hline 16. & $\begin{array}{l}\text { Suspected Fulani herdsmen attacked } \\
\text { Tunari village in Wukari Local } \\
\text { Government }\end{array}$ & $\begin{array}{l}\text { 14th } \\
\text { September, } \\
2014\end{array}$ & $\begin{array}{l}\text { About } 20 \text { people } \\
\text { were killed } \\
\text { including several } \\
\text { buildings } \\
\text { destroyed. }\end{array}$ \\
\hline 17. & $\begin{array}{l}\text { Unknown gunmen attacked Tsundi } \\
\text { town on Sunday }\end{array}$ & $\begin{array}{l}19 \text { October, } \\
2014\end{array}$ & $\begin{array}{l}26 \text { people were } \\
\text { Killed while } 5 \\
\text { people were } \\
\text { wounded and } \\
\text { several people } \\
\text { displaced from } \\
\text { Tsondi town }\end{array}$ \\
\hline 18. & $\begin{array}{l}\text { Unknown assailants attacked and } \\
\text { killed a Jukun along Federal } \\
\text { University road in Wukari .There was } \\
\text { a reprisal attack by Jukun youth the } \\
\text { next day. }\end{array}$ & $\begin{array}{l}\text { On } 7 \\
\text { November, } \\
2014\end{array}$ & $\begin{array}{l}\text { About } 15 \text { people } \\
\text { were killed. }\end{array}$ \\
\hline 19. & $\begin{array}{l}\text { Another violent crisis happened in } \\
\text { Wukari as a result of the November } \\
\text { 7th attack. }\end{array}$ & $\begin{array}{l}\text { On } 8 \\
\text { November, } \\
2014\end{array}$ & $\begin{array}{l}12 \text { people lost } \\
\text { their lives }\end{array}$ \\
\hline 20. & $\begin{array}{l}\text { A violent crisis erupted on at Gidin- } \\
\text { Doruwa a settlement in Wukari Local } \\
\text { Government.Area. }\end{array}$ & $\begin{array}{l}2 \text { December, } \\
2014\end{array}$ & $\begin{array}{l}44 \text { people were } \\
\text { killed, while } \\
\text { several houses } \\
\text { were destroyed. }\end{array}$ \\
\hline
\end{tabular}


A cursory look at the above timeline of the violent ethno-religious conflicts in Wukari Local Government Area of Taraba State reveals that the conflict is primarily rooted in the struggle for political and economic control of Wukari, which assumed ethnic and religious dimensions. The persistent nature of the conflict also indicates that it has become protracted, particularly from April 2014 to date. Generally, the impact of the violent ethno-religious conflicts on inter-group relations in Wukari Local Government Area of Taraba State can be categorized as follows:

- Humanitarian impact

- Economic impact

- Social impact

- Political impact

\section{HUMANITARIAN IMPACT}

Violent ethno-religious conflict in Wukari community has claimed so many lives of the residents of the area, especially Christians and Muslims, Jukun and Hausa/ Fulani. For instance, The People's Daily of Monday June 16, 2014, reported that about thirty-two people were killed in Wukari. The persistent ethno-religious conflicts in the area also led to the displacement of many residents of Wukari. The Guardian Newspaper of Monday, August 18, 2014 indicated that there were many displaced persons from the incidences of ethno-religious conflicts while The Premium Newspaper also observed that over seven hundred (700) people were displaced from Wukari.

\section{ECONOMIC IMPACT}

The persistent ethno-religious conflicts in the Wukari Local Government Area of Taraba State have also negatively impacted the economy of the area. The Tiv farmers whose farming resourcefulness is the mainstay of the economy of Wukari as well as the Igbo traders are now both moving out in large numbers from the area for fear of their lives. This situation has greatly affected commerce and the economy of area.

\section{SOCIAL IMPACT}

Social interactions have been dislocated by the persistent ethno-religious conflicts in the Wukari town and its environs. There is social and psychological separation between the Jukun Christians and the Jukun/ Hausa Muslims, deepened by mutual hatred and suspicion. The violence has also created a divided settlement pattern separating 'Jukun Christian/ jukun traditionalist settlement' and 'Jukun/Hausa Muslim settlement.' By this settlement pattern, neither side could risk crossing to the other side without being killed. 


\section{POLITICAL IMPACT}

Politics in the area has also been negatively impacted by the persistent ethno-religious conflicts in Wukari. The political machinery of the area is controlled by the Jukun Christians and the Jukun Traditionalists. The Jukun Muslims and Hausa Muslims feel excluded from the politics of the area. The Jukun Muslims in particular feel that it is wrong for the Jukun Christians and Jukun Traditionalists to exclude them from what is rightfully theirs and vent their anger and frustration by repudiating and vilifying the Jukun culture, which the Jukun Christians and Jukun Traditionalists perceive as an abomination which must be corrected by all the means possible. During election periods, votes are often cast along religious lines and the Jukun Christians, because of their shear numerical size and the support it enjoys from its allies, the Jukun Traditionalists, dominates the political landscape of Wukari Local Government Area of Taraba State.

\section{SugGESTED SOLUTIONS TO THE MANAGEMENT OF ETHNO-RELIGIOUS CONFLICTS ON INTER-GROUP RELATIONS IN WUKARI LOCAL Government of Taraba State}

Ethno-religious conflict is a common feature of most multi-cultural and divided societies, as Rabushka and Shepsle (1972) assert in their famous work, Politics in Plural Societies: A Theory of Democratic Instability. According to Rabushka and Shepsle, "divided states remain perennially unstable and many survive on the brink of collapse and disintegration." Divided states also lack the capacity to manage the diverse groups interests, as Jinadu (2007) rightly observes about the nature and character of the state:

.. the state and its institutions are ethnicised and immersed in clientelist ethnic and religious networks and in ethnic/religious based struggle to implant and entrench ethnic or religious 'gatekeepers' in critical, key positions in the bureaucracy and educational institutions, and in other public sector institutions and even in the private sector, which in many African countries relies heavily on the public sector (Jinadu, 2007).

Notwithstanding the above position, a very fundamental truth that must be stressed at this juncture is the fact that most conflicts in divided societies have become protracted and irresolvable primarily because people still largely believe that it is only the state that has the capacity, or the magic-wand, to resolve conflicts when it is in fact the state that is generating social conflicts within its domain through its actions and inactions. Rummel (1994) argues that the "government of any state is the greatest 
potential threat to any group inside its boundaries." It is imperative therefore that citizens and communities should understand that they are the ones who need to manage their problems, hence they must establish mechanisms and strategies that will effectively address the problems confronting them. No community or society can exist in isolation of other communities because communities exist interdependently. In this regard, Touval (1985) has rightly observed that the "pluralistic character of most African states has led to the development of mechanisms of adjustment enabling the accommodation of the interests and needs of diverse ethnic groups. Most have developed norms and procedures enabling the maintenance of an ethnic (religious) balance within the political and administrative institutions."

The following suggestions are proffered towards permanently addressing the persistent ethno-religious conflicts in Wukari Local Government Area of Taraba State:

\section{a). Establishment of a Truth and Reconciliation Committee}

Peace, as a valuable gem cannot be decreed unto any society because it requires the collective resolve of all stakeholders in order to plant the seed of peace, nurture it, and harvest its fruits. Peace, therefore, requires true reconciliation among all the stakeholders in any society in order for it to be instituted and sustained. The persistent ethno-religious conflicts in Wukari community have negatively affected the political, economic, social and cultural landscapes of Wukari, with debilitating negative implications on inter-group relations in the area. All of the stakeholders in Wukari, especially the Jukun Christians and Jukun Traditionalists, Jukun Muslims and the Hausa Muslims, should immediately agree to establish a Truth and Reconciliation Committee that will be saddled with the responsibility of reconciling the parties involved in the conflict.

Michael Ignatieff (1996), remarks, "as the African proverb reminds us, 'truth is not always good to say', but when it is shared, it is capable of healing the wounds." Therefore, the establishment of a Truth and Reconciliation Committee (TRC) is important because it will create the platform that will assist the warring parties in Wukari to make sense of the complex issues involved in the conflict as well as reconcile them. As Lerche (2000) argues, all sides have their own version of the truth of "what really happened." The parties will be able to reconcile the issues that had hitherto been irreconcilable. Some of these issues are what Harold Saunders identifies as: "fear, suspicion, rejection, mistrust, (exclusion and marginalization), hatred and misperception which are often greater obstacles to peace than an inability to resolve technically definable problems“. 


\section{b). Power Sharing Arrangement}

It is a fact that most and if not all ethno-religious conflicts are inextricably linked to the competition for political and economic resources and the tool that is often used in such competition is identity politics which is usually done by invoking the dare-devil politics of indigene versus settler dichotomy. In this contest, an indigene is perceived to be somebody who is historically affiliated to the place or town or community or locality being contested for and by the virtue of his/her affiliation to the place, he/she enjoys some certain rights and benefits that those who are considered as settlers in the area cannot enjoy.

On the other hand, a settler is perceived as a person who does not have historical affiliation to a place or town or community or locality, due to this, he or she is excluded from enjoying certain rights and benefits that those who considers themselves indigenous to the place enjoy. This kind of perception and definition is a total violation of the concept of citizenship which is supposed to guarantee every bona fide citizen the legal right to enjoy the basic rights and benefits available in any part of a sovereign state. This is the reason why Ibrahim (2000:69) argues that ethno-religious conflicts in Nigeria are linked to citizenship within the context of identity, which is rooted in the politics of inclusion or exclusion. These are tied to claims and counter-claims over identity as a basis for determining who is excluded or included from decision making as well as access to opportunities under the 'we' versus 'them' cliché (Kwaja, 2008:83). At the core of ethnic agitations and conflicts are "distributive questions, which are the fundamental sources of ethnic tensions in Nigeria" (Nnoli 1978 and 1994).

As pointed out by the Carnegie Commission on Preventing Deadly Conflicts (1997:100):

In many multi-ethnic and multi-religious societies, the procedures of majoritarian democracy have proven effective for managing group relations and maintaining social cohesion. However, in societies with deep ethnic and religious divisions and little experience with democratic government and the rule of law, strict majoritarian democracy can be self-defeating. Where ethnic and religious identities are strong and national identity weak, the population may vote largely along ethnic or religious lines. Domination by one ethnic or religious group(s) can lead to a tyranny of the majority [emphasis added] (100).

Indeed, it is always very important for communities and societies experiencing conflict to avoid both the tyranny of the majority and the 
revengeful terrorism of the minority, and to understand that they have to work together to resolve their differences so as to build a just and fair community or society in which the rights and interests of all can be guaranteed. This example can also be applied to the Wukari case. Both the Jukun Christians and the Jukun Traditionalists who are the majority in Wukari Local Government Area of Taraba State and the minority Jukun Muslims who are always in alliance with the Hausa Muslims in the area must come to the understanding that they need to work out an inclusive political arrangement that would give both sides, and even the other groups resident in the area, the sense of belonging in the political architecture of Wukari. This is especially because some researchers on conflict management have pointed out that the openness of political institutions decreases the chances of occurrences of violent conflict and protests (e.g., Kriesi, Koopmans, Duyven-dak and Giugni, 1995). This is important because inclusive political arrangements reduce the tendency of competing groups resorting to violent agitations. The adoption of this practice will therefore assist in the accommodation of diversity, which will allay the fears of both the ethnic and religious minorities in the area as well as guarantee the protection of the rights of all the residents of Wukari. In addition, it will assist in the transformation of the perception of ethnic and religious loyalties from being a threat to the social cohesion of Wukari to being utilized as an engine of socio-economic development.

\section{CONCLUSION}

Religion and ethnicity are two very important tools that the elites in Nigeria employ in constructing and mobilizing identity in competitive situations. Identity politics have resulted in violent and uncontrollable conflicts of different intensity and magnitudes. The major task of this paper has been to examine the dynamics of the persistent ethno-religious conflicts in Wukari area of Taraba State, Nigeria and the possibility for its sustainable management. The paper therefore proposed some very robust strategies for tackling the persistent ethno-religious conflicts in Wukari community with a view to making all the residents of Wukari, regardless of their ethnic or religious divide, work out some kind of modus vivendi that would enable them to accommodate each other and peacefully coexist. This is with the understanding that no community can exist in isolation of other communities hence communities exist interdependently.

\section{REFERENCES}

Albert, I.O. eds. 2001. Ife-Modakeke crisis. In Otite, O \& Albert, I.O. Community Conflicts in Nigeria: Management, Resolution and Transformation. Ibadan: Spectrum Books Limited. 
Armed Conflict Location \& Event Dataset (ACLED), www.acleddata .com

Ballard, R. 1996. "Negotiating race and ethnicity: exploring the implications of the 1991 census," Patterns of Prejudice. Pp. 3-33.

Bulmer, M. 1996. "The ethnic group question in the 1991 Census of Population." In Ethnicity in the 1991 Census. Volume 1. Demographic characteristics of the ethnic minority populations, Coleman D, Salt J (eds.), Office for National Statistics, HMSO: London: xi $-\mathrm{xxix}$.

Carnegie Commission, 1997. "Preventing Deadly Conflicts: A Final Report", Washington, DC: Carnegie Commission.

CLEEN Foundation 2012. Justice Sector Reform, Summary of Findings of 2012 National Crime and Safety Survey. p.3.

Coleman, D. and Salt. J. 1996. Ethnicity in the 1991 census population. HMSO.

Conversi, D. 1999. "Nationalism, Boundaries and Violence" Milllenium Vol.28.

Debiel, T. 2002. "Do crisis regions have a chance of lasting peace? The difficult transformation from structures of violence." Fragile Peace, State Failure, Violence and Development in Crisis Regions. London. Zed Books. 1-20.

Etanibi, E O. and Alemika, S. 2000. "A sociological analysis of ethnic and religious conflicts in the middle belt of Nigeria, in ethnic and religious rights." A Quarterly Publication of Human Rights Monitor, Special Edition, edited by Festus Okeye, April 2000, Kaduna Nigeria.

Fund for Peace, 2013. The Failed States Index 2013, http://ffp.statesin dex.org/rankings-2013-sortable.

Hopkins A. G. 1973. An Economic History of West Africa. London: Longman.

Ibrahim, J. 1999. "Ethno-Religious Mobilisation and Sapping of Democracy in Nigeria" in Hyslop, J. (ed.) African Democracy in the Age of Globalisation. Wit water-rand University Press.

Ibrahim, J. 2000. "The Transformation of Ethno-Religious Identities in Nigeria." In Jega, A (ed) Identity Transformation and Identity Politics under Structural Adjustment in Nigeria, Stockholm, Elanders Gotab. 
Ignatieff, Michael. 1996. Articles of Faith." Abridged from the article published in Index On Censorship, 5(96), September. URL located at: http://www.niza.nl/uk/pubications/001/ignatieff.htm

Jega, A.M. 2002. "Tackling Ethno-Religious Conflicts in Nigeria." The Nigeria Social Scientist 5 (2) Pp. 35-39.

Jinadu, A. L. 2007. "Explaining \& Managing Ethnic Conflicts in Africa: Towards a Cultural Theory of Democracy," Claude Ake Memorial Paper Series (CAMP) No.1, Uppsala: The Nordic Africa Institute.

Kwaja, A.M.C. 2008. "Ethnic and Religious Conflicts in Wase LGA, Plateau State, Nigeria," in Best, S.G (ed) Causes and Effects of Conflicts in the Southern Zone of Plateau State, Nigeria, Ibadan, John Archers Publishers Limited.

Kriesi, Ha., Koopmans, R., Duyvendak, J. W. and Giugni.M. G. 1995. New Social Movements in Western Europe: A Comparative Analysis. Minneapolis: University of Minnesota Press.

Lerche, Charles O., III. 2000. "Truth Commissions and National Reconciliation: Some Reflections on Theory and Practice." Peace and Conflict Studies, 7(1), May, 2000.

Lewis, P., and Bratton, M. 2000. "Attitudes Towards Democracy and Markets in Nigeria: Report of a National Opinion Survey," JanuaryFebruary 2000, Washington, DC: International Foundation For Election Systems and Management Systems International.

Mohammed, H. 2004. "Plateau. Crises: The Press as the No.1. Culprit," Daily Trust, June 30, 2004.

Mitchel, T. G. 2000. Native vs settlers; ethnic conflict in Israel/ Palestine, Northern Ireland, and South Africa Westport; Greenwood press.

Modood, T., Berthoud, R., Lakey, J., Nazroo, J., Smith, P., Virdee, S. and Beishon, S. 1997. Ethnic Minorities in Britain: Diversity and Disadvantage. London: Policy Studies Institute.

Momodu, A. Jude 2014. The Challenges of Government Institutions and Non-Governmental Organisations in the Management of Tiv-Jukun Conflicts in Wukari, Taraba State. Unpublished Ph.D. Dissertation, Peace and Conflict Studies Programme, Institute of African Studies, University of Ibadan, Nigeria.

Nnoli, O. 1978. Ethnic Politics in Nigeria, Enugu, Fourth Dimension Publishers.

Olaniyi R. 2001. "Urban Violence, Ethnic Conflicts and Diaspora Identity: The Experience of the Yoruba Community in Metropolitan Kano, Nigeria." In: Eruvebetine E. (Ed.). Rethinking the Flame of 
Development through a Humanistic Management of Pluralism. Lagos: Faculty of Arts, University of Lagos.

Okwueze, M. L.1995. Religious Problems and Conflict in Nigeria Revisited; Contemporary Issues in Social Sciences, Enugu; Acena publishers.

Omohan, S. O. 2005. "Management of ethno- religious conflicts; the Nigerian experience." In A.M.Yakubu, Crisis since 1980. Kaduna; Baraka press and publishers Ltd.

Quaker-Dokubo, C. 2001. "A Nigerian case study". Paper presented at a conference at the University of Pretoria, 25-26 July 2001. In Politics of Identity and Exclusion in Africa: from Violent Confrontation to Peaceful Cooperation, pp. 43-56.

Rabushka, Alvin and Kenneth A. Shepsle 1972. Politics in Plural Societies: A Theory of Democratic Instability, Columbus: Charles E. Merrill

Ross, M. 2000. "Good- enough isn't so bad; thinking about success and failure in ethnic conflict management peace and conflict" Journal of Peace Psychology, 6 (1) 27-47.

Rummel, R. J. 1994. Death by government: Genocide and Mass Murder since 1900", New Brunswick NJ, Transaction Publishers.

Saunders, A Public Peace Process, 74.

Solomos, J. and Back. L. 1996. Racism and Society. London: Macmillan.

Swindell, K. 1984. "Farmers, Traders and Labourers: Dry Season Migration from the North-West Nigeria 1900-1930". AFRICA: J. Int. Institute 54(1). The News, January 24, 2000.

Takaya, B. J. 1992. "Religion, Politics and Peace: Resolving the Nigerian Dilemma", in Olupona, J. K. (ed) Religion and Peace in a Multifaith Nigeria, Ile-Ife, Obafemi Awolowo University Press.

The Fund for Peace, 2007. 'The Failed States Index 2006'. Internet: http://www.fundforpeace.org/programs/fsi/fsindex2006.php, accessed 24 August 2014.

Transparency International (TI), 26 September, 2007. 'Corruption Perceptions Index 'Internet http://www.transparency.org/news_room/ in_focus/2007/cpi2007/cpi_2007 table accessed 17 November, 2014.

Usman. Y. B. 1981. The Transformation of Katsina, 1000-1883. Zaria: Ahmadu Bello University Press. 
Vision of Humanity, Global Peace Index, 2013. Nigeria, http:// www.visionofhumanity.org/\#page/indexes/global-peace-index/2013/ NGAVOVER.

Zartman, W. I. 1989. Ripe for Resolution: Conflict and Intervention in Africa, New York: Oxford University Press, 269.

Willigenburg, T. 1995. Nation, State and the Coexistence of Different Communities. Kampen: Kok. 